\title{
С.Г. Лузянин
}

\section{РЕЦЕНЗИЯ: БЫЧКОВА Т.А. СТРАНЫ АЗИИ НА ПУТИ ОТ ТРАДИЦИОННОГО ОБЩЕСТВА К ИНДУСТРИАЛЬНОМУ (ХVIІ - НАЧАЛО ХХ в.) : УЧЕБ. ПОСОБИЕ / ПОД РЕД. В.П. ЗИНОВЬЕВА. ТОМСК : ИЗДАТЕЛЬСКИЙ ДОМ ТОМСКОГО ГОСУДАРСТВЕННОГО УНИВЕРСИТЕТА, 2014. $460 \mathrm{c}$.}

В учебном пособии Т.А. Бычковой «Страны Азии на пути от традиционного общества к индустриальному (XVII - начало XX в.)» на основе широкого круга литературы и источников рассматривается история народов Азии (Китая, Японии, Индии, Ирана и Османской империи) с XVII по начало XX в. как переходный период от традиционного общества к индустриальному, акцентируя при этом внимание на сложных, противоречивых сторонах процесса модернизации, который был не естественным, эндогенным, а навязанным извне (экзогенным) и проходящим в условиях колониальной и полуколониальной зависимости стран Азии.

Особенностью переходного периода, как отмечает автор пособия, стала его длительность - Китай переходил от традиционного общества к индустриальному с середины XIX в. до середины XX в., Индия проделала этот путь в течение 150 лет. Трансформация традиционных экономических, политических, социальных институтов в соответствующие институты индустриального общества определила для стран Азии путь «догоняющего», «периферийного» развития.

Как известно, история нового времени - это история распространения, утверждения и доминирования европоцентристского мира в пределах практически всей планеты. Государства Азии с XVII по начало $\mathrm{XX}$ в. прошли свою часть пути вхождения в мировую капиталистическую систему и международное разделение груда, в чём-то сохранив традицию, в чём-то заимствовав правила игры западных стран.

Наиболее важные события рассматриваемого периода в учебном пособии подаются через реакцию стран
Азии на ограничение их суверенитета со стороны стран Запада и последовавшим в результате этого ухудшением качества жизни масс населения.

Правящая элита, пытаясь сохранить власть и в то же время выполнять неравноправные договоры с иностранными державами, занялась реформаторской деятельностью, а население отвечало на политику держав и собственных правителей крестьянскими войнами и восстаниями, революциями. Показаны позитивные и негативные проявления и последствия воздействия колониальной системы на экономическое, политическое и социальное развитие стран Азии.

Пособие Т.А. Бычковой отличает не только раскрытие социально-экономических и политических процессов, но и стремление показать духовные портреты китайца, японца, индийца, иранца, турка периода существования традиционных обществ.

Учебное пособие снабжено контрольными вопросами, сопровождающими все разделы, программой дисциплины «Страны Азии на пути от традиционного общества к индустриальному (XVII - начало $\mathrm{XX}$ в.)», а также достаточно обширным списком источников и литературы, написано хорошим литературным языком.

Книгу отличает высокое полиграфическое исполнение.

Пособие рассчитано на студентов международного отделения, а также студентов-историков. Оно позволяет составить представление о тенденциях развития стран Азии в новое время и облегчить понимание современных проблем этих стран.

Luzyanin Sergey G. Institute of Far Eastern Studies, Russian Academy of Sciences (Moscow, Russian Federation). E-mail: lousianin@ifes-ras.ru

REVIEW: BYCHKOVA T.A. THE COUNTRIES OF ASIA ON THE WAY FROM TRADITIONAL SOCIETY TO INDUSTRIAL (XVII - THE BEGINNING OF THE XX CENTURY): THE MANUAL / ED. BY V.P. ZINOVYEV. TOMSK : PUBLISHING HOUSE OF TOMSK STATE UNIVERSITY, 2014.460 p. 